\title{
Sosialisasi Kasus-Kasus Terkait Manual Coding dan Modern Coding Pada Dispute Claim
}

\author{
Yastori* \\ Program Studi DIII Ilmu Rekam Medis, Apikes Iris, Padang, Indonesia \\ *yastorivi@gmail.com
}

\begin{abstract}
ABSTRAK
Kesesuaian kompetensi alumni dengan kebutuhan stakeholder merupakan hal yang krusial dalam perkembangan dan kemajuan ilmu pendidikan. Seperti perbedaan antara manual coding dengan modern coding menjadi salah satu permasalahan yang sering muncul bagi perekam medis dilapangan kerja. Ketepatan pengodean dapat berpengaruh terhadap pembayaran seperti kepada pihak pemberi asuransi. Tujuan sosialisasi yaitu memberikan gambaran contoh-contoh kasus terkait manual coding dan modern coding pada dispute claim dirumah sakit kepada perekam medis, dokter dan mahasiswa. Metode pengabdian kepada masyarakat dalam bentuk sosialisasi pada seminar online dengan menggunakan aplikasi Zoom pada Sabtu, 08 Agustus 2020 dengan 299 orang peserta. Sosialisasi dilakukan dalam bentuk penyampaian materi, diskusi dalam bentuk tanya jawab dan memberikan latihan contoh soal kepada peserta. Pada sosialisasi disampaikan contohcontoh kasus manual coding dan modern coding pada dispute claim yang diambil dari beberapa rumah sakit di kota Padang, kemudian dijelaskan apa yang menyebabkan pengodean pada diagnosis dan tindakan tersebut mengalami dispute claim. Pada penyajian penjelasan dibatasi dari sudut pandang akademik yaitu berdasarkan ICD-10 dan ICD 9 CM oleh WHO. Setelah dilakukan sosialisasi, peserta seminar yang terdiri dari perekam medis, dokter, mahasiswa dan tenaga kerja dibidang pengodean lebih memahami penyebab dispute claim dari contoh kasus yang diberikan. Peningkatan pemahaman terkait ketepatan pengodean diagnosis dan tindakan dapat meminimalisir terjadinya dispute claim.
\end{abstract}

Kata Kunci: Dispute claim, Manual coding, Modern Coding

Received: August 2, 2020

Revised: August 20, 2020

Accepted: August 30, 2020

This is an open-acces article distributed under the terms of the Creative Commons Attribution-ShareAlike 4.0 International License.

\section{PENDAHULUAN}

Keakurasian dalam pengodean suatu penyakit dan tindakan sangatlah penting karena terkait dengan pembiayaan pelayanan kesehatan. Beberapa penelitian terdahulu telah membahas keakuratan koding terhadap pembiayaan rumah sakit, namun jumlah studi yang menyelidiki penyebab pengembalian klaim hasil verifikasi BPJS terkait akurasi koding masih terbatas. Ketepatan pengodean dapat berpengaruh terhadap pembayaran seperti pembayaran kepada pihak peberi asuransi. Kode pada pasien dianggap tepat dan akurat apabila sesuai dengan kondisi pasien dengan segala tindakan yang terjadi, lengkap sesuai aturan klasifikasi yang digunakan. Berdasarkan standar dan etik pengodean yang dikembangkan AHIMA bahwa seorang petugas koding (coder) 


\section{Journal of Community Engagement in Health}

profesional haruslah menentukan kode secara akurat, komplit dan konsisten untuk menghasilkan data yang berkualitas. Penetapan diagnosis dan tindakan medis seorang pasien merupakan kewajiban, hak dan tanggung jawab dokter (tenaga medis) yang terkait tidak boleh diubah oleh karenanya harus diagnosis dan tindakan medis yang ada dalam rekam medis diisi dengan lengkap dan jelas sesuai arahan yang ada pada buku ICD 10 dan ICD-9- CM. (Depkes RI, 2006).

Permasalahan pada tahapan pelaksanaan klaim seperti ketidaklengkapan berkas, ketepatan kode diagnosis ditemukan dalam penelitian yang dilakukan oleh Tuti (2010) yang menemukan penyebab ketidaklengkapan berkas klaim pasien Jamkesmas disebabkan beban kerja terlalu besar, sistem informasi dan sistem administrasi yang kurang memadai serta kurangnya disiplin sumber daya manusia. Penelitian yang dilakukan Tuti didukung dengan hasil penelitian Mahmud Kusairi menemukan bahwa, proporsi beban kerja petugas administrasi klaim sangat rendah. Waktu yang digunakan oleh petugas hanya $7,4 \%$ perhari, waktu kerja produktif yang optimum berkisar $80 \%$ perhari, kinerja petugas coding dalam melakukan pengcodingan belum maksimal dan 23,3\% terjadi ketidaksesuaian dalam penetapan kode diagnosis (Kuasairi, 2013). Kesalahan dalam pengodean diagnosis penyakit akan memberikan implikasi kepada klaim. Dalam pengodean diagnosis yang akurat, lengkap dan konsisten akan menghasilkan data yang berkualitas. Ketepatan dalam pemberian kode diagnosis merupakan hal penting yang harus diperhatikan oleh tenaga perekam medis, kualitas data terkode merupakan hal penting bagi kalangan tenaga personel Manajemen Informasi Kesehatan. Ketepatan data diagnosis sangat krusial di bidang manajemen data klinis, penagihan kembali biaya, beserta hal-hal lain yang berkaitan dengan asuhan dan pelayanan kesehatan (Hatta. GR, 2008). Ketidaktepatan pada pengodean diagnosis dan prosedur dapat menyebabkan terjadinya dispute claim atau penundaan klaim oleh pihak pemberi asuransi. Tujuan sosialisasi ini yaitu untuk memberikan gambaran contoh-contoh kasus terkait manual coding dan modern coding pada dispute claim dirumah sakit kepada perekam medis, dokter dan mahasiswa.

\section{METODE}

Metode Pengabdian Kepada Masyarakat (PKM) dalam bentuk sosialisasi pada seminar online dengan menggunakan aplikasi Zoom. Sosialisasi dilakukan dalam bentuk penyampaian materi, diskusi dalam bentuk tanya jawab, evaluasi dalam bentuk memberikan latihan contoh soal untuk mengetahui pemahaman peserta.

\section{HASIL}

Pengabdian kepada masyarakat dalam bentuk sosialisasi pada seminar online dengan menggunakan aplikasi Zoom pada Sabtu, 08 Agustus 2020 dengan 299 orang peserta. 


\section{Journal of Community Engagement in Health}

http://jceh.org

ISSN: 2620-3758 (print); 2620-3766 (online)

https://doi.org/10.30994/jceh.v3i2.72

Vol.3 No.2. Sep 2020. Page.246-251

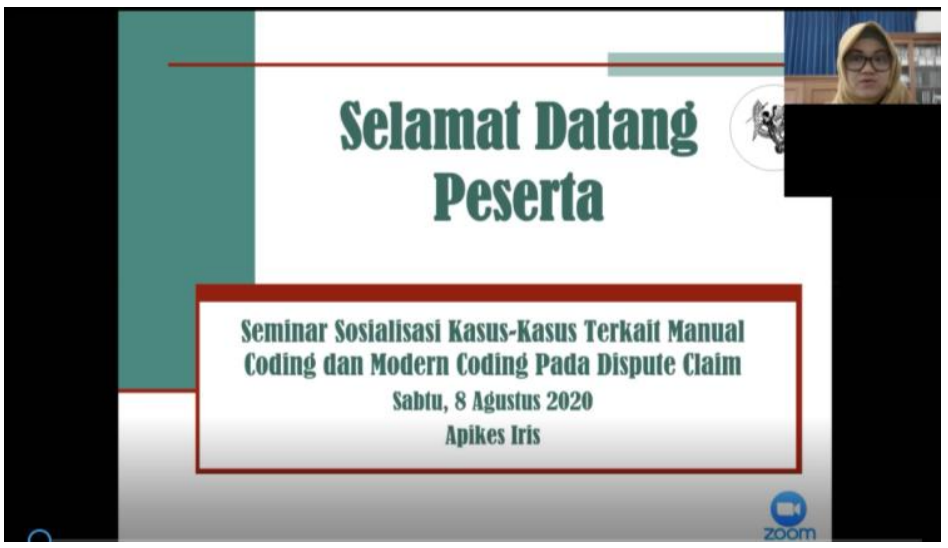

Gambar 1. Penyampaian materi oleh Ketua Pengabdi Yastori, M.Si

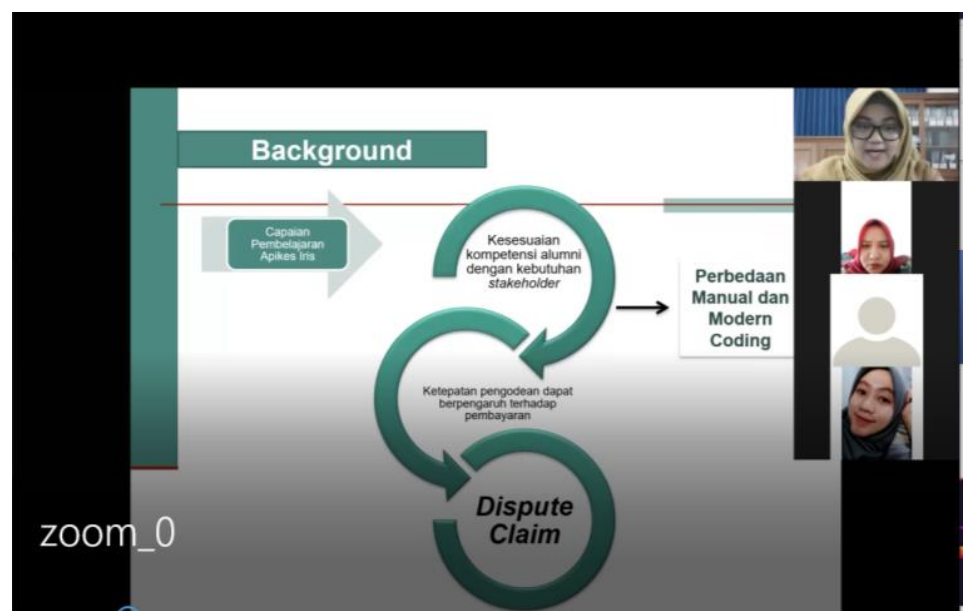

Gambar 2. Penjelasan latar belakang pelaksanaan Pengabdian Kepada Masyarakat

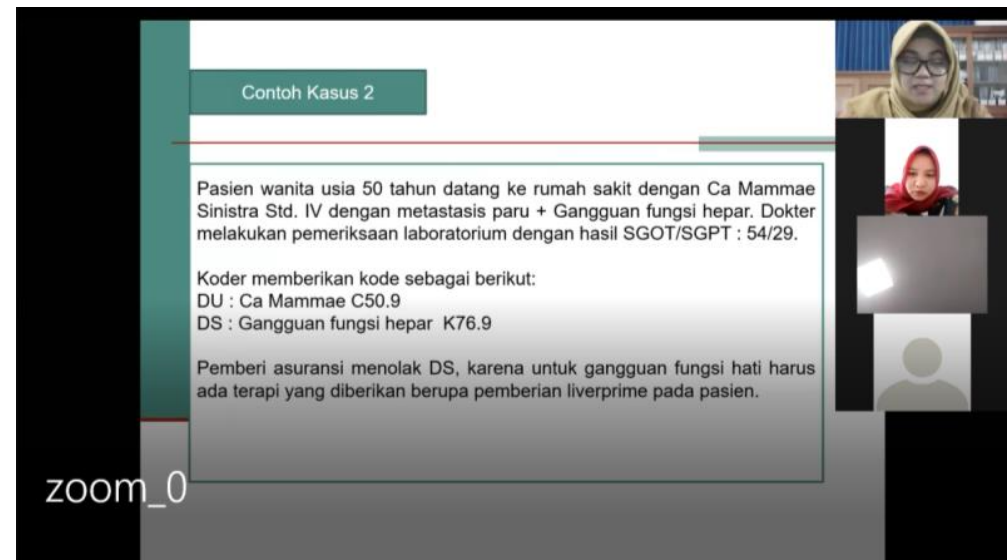

Gambar 3. Penjelasan materi dalam bentuk pembahasan contoh-contoh kasus terkait manual coding dan modern coding pada dispute claim 


\section{Journal of Community Engagement in Health}

http://jceh.org

ISSN: 2620-3758 (print); 2620-3766 (online)

https://doi.org/10.30994/jceh.v3i2.72

Vol.3 No.2. Sep 2020. Page.246-251

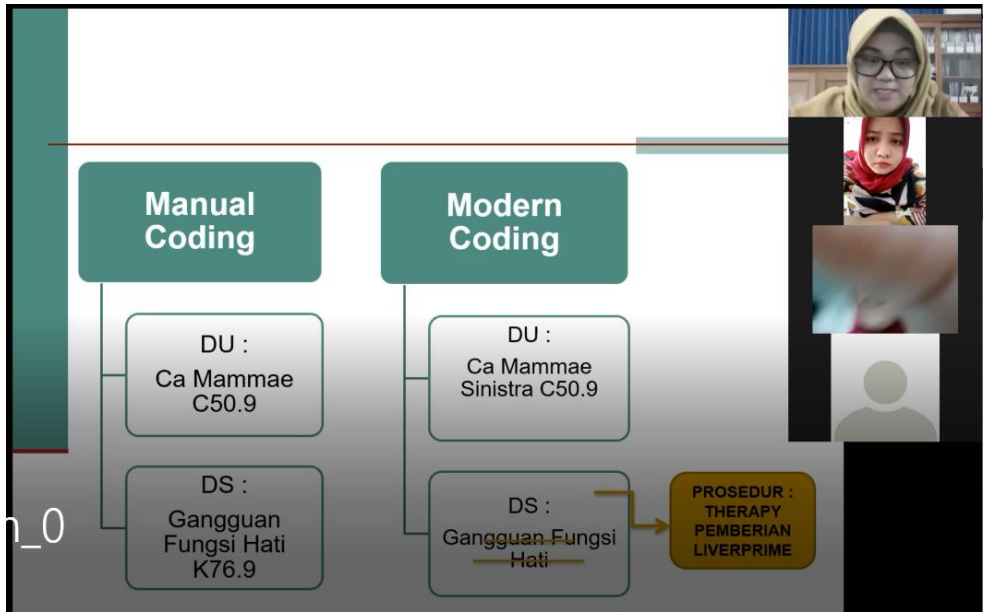

Gambar 4. Pembahasan contoh-contoh kasus dari segi sudut pandang akademik berdasarkan ICD-10 dan ICD 9 CM, WHO 2016

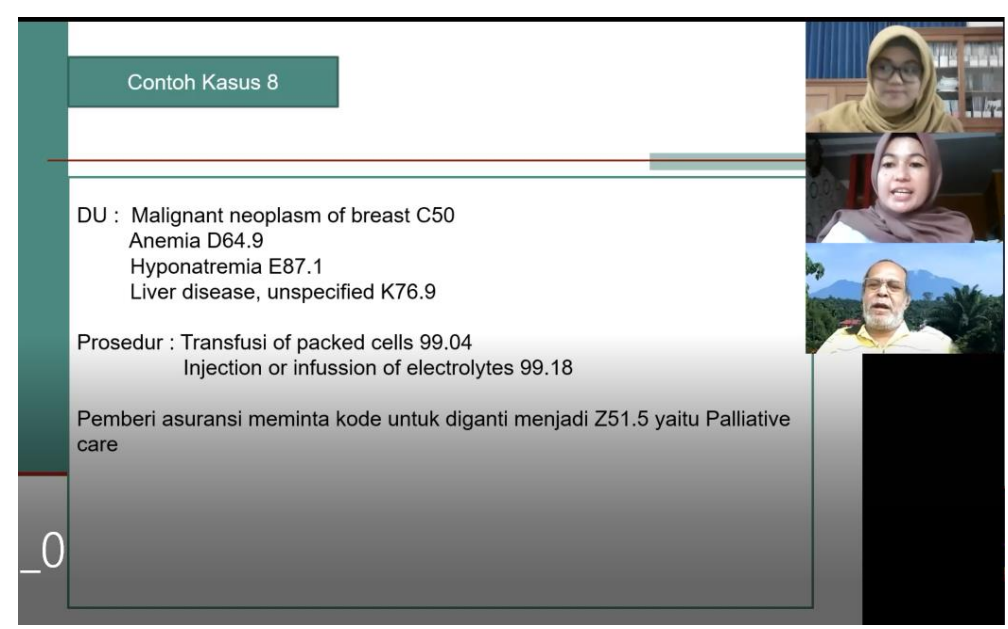

Gambar 5. Diskusi terkait contoh-contoh kasus manual coding dan modern coding pada dispute claim dengan ahli dr. Erkadius, M.Sc

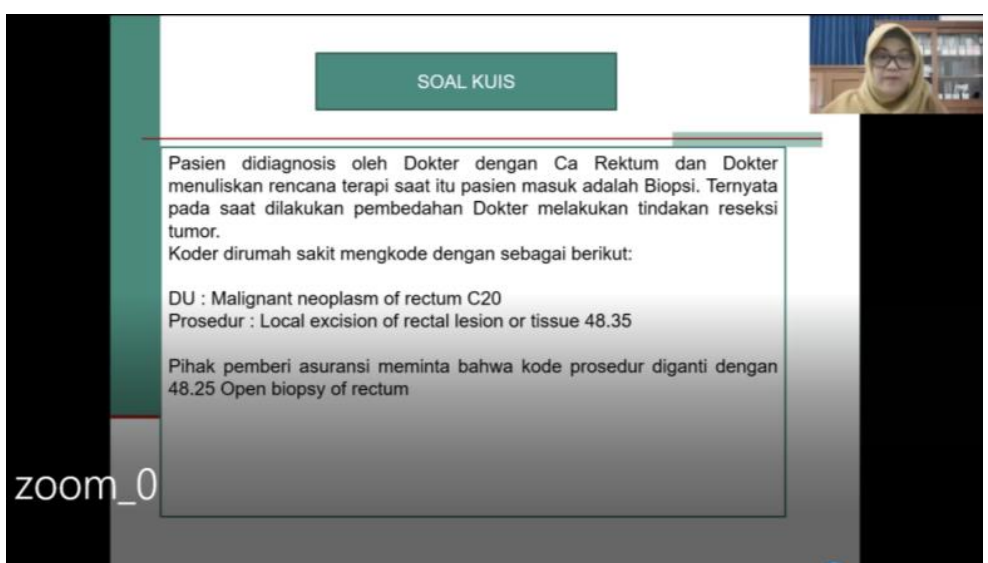

Gambar 7. Pemberian contoh soal dalam bentuk kuis kepada peserta seminar 


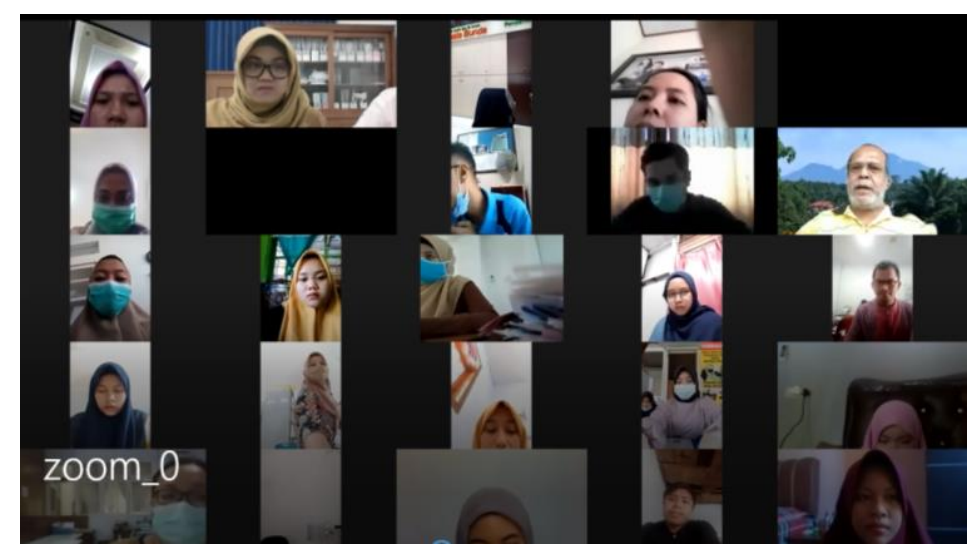

Gambar 8. Dokumentasi peserta seminar menggunakan aplikasi Zoom

\section{PEMBAHASAN}

Pengabdian Kepada Masyarakat (PKM) telah dilaksanakan dalam bentuk sosialisasi pada seminar online menggunakan aplikasi Zoom dengan 299 orang peserta. Kegiatan PKM ini dilaksanakan dengan beberapa persiapan diantaranya, pembuatan flyer acara seminar online, pembuatan formulir pendaftaran menggunakan google form, pembuatan akun Zoom, pembuatan link pendaftaran peserta, penerimaan pendaftaran peserta dan pelaksanaan seminar online, penyerahan sertifikat dan materi kepada peserta.

Sosialisasi dilakukan dalam bentuk penyampaian materi, pada penyampaian materi dijelaskan latar belakang perlunya disampaikan contoh-contoh kasus terkait manual coding dan modern coding dan dispute claim. Bagaimana peran perekam medis, dokter dan tenaga kerja yang berkaitan dengan pengodean diagnosis dan prosedur pada instansi kesehatan. Setelah disampaikan contoh-contoh kasus dilanjutkan dengan penjelasan perbandingan manual coding dan modern coding dari segi sudut pandang akademik berdasarkan ICD-10 dan ICD 9 CM oleh WHO Tahun 2016 kemudian dilanjutkan penjelasan pengodean diagnosis dan prosedur tersbut mengalami dispute claim oleh pihak pemberi asuransi. Setelah penyampaian materi dilanjutkan dengan diskusi dalam bentuk tanya jawab oleh peserta dengan Ketua Pengabdi dan dilanjutkan diskusi dengan pembicara tamu yang merupakan ahli dalam pengodean yaitu dr. Erkadius, M.Sc. Setelah dilakukan tanya jawab, dilakukan evaluasi terhadap pemahaman peserta seminar dalam bentuk pemberian soal latihan berupa kuis.

Setelah dilakukan sosialisasi, peserta seminar yang terdiri dari perekam medis, dokter, mahasiswa dan tenaga kerja dibidang pengodean lebih memahami penyebab dispute claim dari contoh kasus yang diberikan. Peningkatan pemahaman terkait ketepatan pengodean diagnosis dan tindakan dapat meminimalisir terjadinya dispute claim.

\section{KESIMPULAN}

Kegiatan Pengabdian Kepada Masyarakat (PKM) ini dapat menambah wawasan dan meningkatkan pemahaman perekam medis, dokter, mahasiswa rekam medis dan tenaga kerja dibidang pengodean terkait ketepatan pengodean diagnosis dan prosedur pada dispute claim. 


\section{Journal of Community Engagement in Health}

http://jceh.org

ISSN: 2620-3758 (print); 2620-3766 (online)

https://doi.org/10.30994/jceh.v3i2.72 Vol.3 No.2. Sep 2020. Page.246-251

\section{UCAPAN TERIMAKASIH}

Ucapan terimakasih kepada Apikes Iris yang telah mendanai kegiatan Pengabdian Kepada Masyarakat ini pada Program Hibah PKM Tahun 2020

\section{REFERENSI}

Depkes RI. 2006. Pedoman Penyelenggaraan dan Prosedur Rekam Medis Rumah Sakit. Jakarta: Departemen Kesehatan.

Hatta, G, R. 2008. Pedoman Manajemen Informasi Kesehatan di Sarana Pelayanan Kesehatan.

Kusairi, M. Faktor-faktor yang Mempengaruhi Kelengkapan berkas Klaim pasien Jamkesmas di RSUD Brigjend $\mathrm{H}$ Hasan Basry Kandangan [Tesis]. 2013. Yogyakarta: UGM. UI-PRESS.

Tuti. Evaluasi Klaim Jamkesmas di RSUD Dr Zainal Abidin Banda Aceh [Tesis]. Yogyakarta: UGM; 2010. 